\title{
Estimating the genetic diversity and structure of Quercus trojana Webb populations in Italy by SSRs: implications for management and conservation
}

\begin{tabular}{|r|l|}
\hline Journal: & Canadian Journal of Forest Research \\
\hline Manuscript ID & cjfr-2016-0311.R1 \\
\hline Manuscript Type: & Article \\
\hline Complete List of Authors: & $\begin{array}{l}\text { Carabeo, Maddalena; CNR-Institute of Agro-environmental and Forest } \\
\text { Biology, Ist. Biologia Agroambientale e Forestale } \\
\text { Simeone, Marco Cosimo; Universita degli Studi della Tuscia, Agricoltura, } \\
\text { Foreste,Natura e Energia } \\
\text { Cherubini, Marcello; CNR-Institute of Agro-environmental and Forest } \\
\text { Biology, } \\
\text { Mattia, Chiara; Parco Nazionale dell'Alta Murgia, Ministero dell'Ambiente } \\
\text { Chiocchini, Francesca; CNR-Institute of Agro-environmental and Forest } \\
\text { Biology, } \\
\text { Bertini, Laura; Universita degli Studi della Tuscia, Ecologia e Scienze } \\
\text { Biologiche } \\
\text { Caruso, Carla; Universita degli Studi della Tuscia, Ecologia e Scienze } \\
\text { Biologiche } \\
\text { La Mantia, Tommaso; Università degli Studi di Palermo, Italy, } \\
\text { Dipartimento di Scienze Agrarie e Forestali } \\
\text { Villani, Fiorella; CNR-Institute of Agro-environmental and Forest Biology, } \\
\text { Mattioni, Claudia; CNR-Institute of Agro-environmental and Forest Biology, } \\
\text { Ist. Biologia Agroambientale e Forestale }\end{array}$ \\
\hline Keyword: & $\begin{array}{l}\text { <i>Quercus trojana</i>, Genetic diversity, Population structure, SSRs } \\
\text { markers, Conservation }\end{array}$ \\
\hline
\end{tabular}


1 Estimating the genetic diversity and structure of Quercus trojana Webb populations in Italy

2 by SSRs: implications for management and conservation

3 Maddalena Carabeo ${ }^{1}$, Marco Cosimo Simeone ${ }^{2}$, Marcello Cherubini ${ }^{1}$, Chiara Mattia ${ }^{3}$, Francesca 4 Chiocchini $^{1}$, Laura Bertini ${ }^{4}$, Carla Caruso ${ }^{4}$, Tommaso La Mantia ${ }^{5}$, Fiorella Villani ${ }^{1}$, Claudia 5 Mattioni $^{1}$

6

7 (1) Istituto di Biologia Agroambientale e Forestale (CNR), Porano Italy

8 (2) Dipartimento di Agricoltura, Foreste, Natura e Energia, Università della Tuscia, Italy

9 (3) Parco Nazionale dell'Alta Murgia, Ministero dell' Ambiente, Italy;

10 (4) Dipartimento di Ecologia e Scienze Biologiche Università della Tuscia, Italy

(5) Dipartimento di Scienze Agrarie e Forestali, Università degli Studi di Palermo, Italy;

maddalenacarabeo@gmail.com;

mcsimeone@unitus.it;

marcello.cherubini@baf.cnr.it

chiaramattia@parcoaltamurgia.it

francesca.chiocchini@baf.cnr.it

lbertini@unitus.it

caruso@unitus.it,

tommaso.lamantia@unipa.it

fiorella.villani@baf.cnr.it

Corresponding author: Claudia Mattioni Istituto di Biologia Agroambientale e Forestale (CNR) Porano, Italy. email: claudia.mattioni@ibaf.cnr.it 


\section{Abstract}

Studying the genetic diversity and structure of the current forest populations is essential for evaluating the ability to survive to future biotic and abiotic changes and planning conservation strategies. Quercus trojana is an eastern Mediterranean tree species with a fragmented distribution range, and its westernmost outposts are located in southern Italy. The demand for timber and cropland over the centuries has severely reduced its occurrence in this part of the range. We assessed the genetic diversity and structure of the extant Italian populations of $Q$. trojana and derived conservation guidelines. A total of 322 samples were genotyped with six polymorphic nuclear microsatellite markers. A high genetic diversity in all populations, two main gene pools, and a highly divergent single population were observed. Based on the allelic richness and heterozygosity estimation, we identified populations which can be considered as valuable source material for conservation programs, and those requiring adequate measure to re-establish gene flow and reduce fragmentation. Finally, a comparison with a set of eastern Mediterranean samples indicated a relationship between the Italian and the Greek gene pool. The need to protect these marginal, disjunct populations was further reinforced.

53 


\section{Introduction}

Forests are considered the most complex terrestrial ecosystems due to their high level of biodiversity in term of genetic resources, species and habitat (Geburek and Konrad 2008). However, the degradation and disappearance of natural forests occurred in the last centuries have caused serious biodiversity losses. An important indicator of biodiversity is the amount of genetic diversity (Shachak et al. 2008) that is widely recognized as the key component for the long-term survival of a species (Gapare 2014). Genetic diversity is a foundation of sustainability providing raw material for adaptation, evolution and survival, especially under changing environmental and disease conditions (Reed and Frankham 2003). Hence, studies addressing levels of genetic diversity can help to reduce the risk of loss of biodiversity by identifying the populations and areas that show high values of genetic variability and merit the most attention in terms of conservation priority (Suoto et al. 2015). In this context in situ and ex situ conservation plans must consider the intraspecific genetic variation as fundamental criterion for developing effective conservation strategies (Eckert et al. 2008). Many studies on tree genetic diversity can provide evidence for the long term influence of forest management and /or exploitation on the tree populations; in some cases, a reduction in allelic richness, in the number of rare alleles and heterozygosity was observed (Patuasso 2009). Moreover, habitat fragmentation affects genetic diversity due to the alteration in the landscape features which leads to reduced gene dispersal (Oddou -Muratorio and Klein 2008). The loss of genetic diversity through genetic drift and increased selfing can cause the local extinction of small populations (Honnay and Jacquemyn 2007). In this context it is of great importance to assess the genetic diversity and patterns of gene flow of $Q$. trojana Italian extant populations, to understand its current evolutionary and adaptive trends and provide scientific basis for "conservation in practice".

Quercus trojana Webb is an eastern Mediterranean/Balkan oak belongs to the subgeneric Quercus, group Cerris (Denk and Grimm 2010; Simeone et al. 2013). This is a Eurasian oak clade with an inferred Miocene origin (Hubert et al., 2014) consisting of evergreen, semi-evergreen and 
90

91

92

93

94

95

96

97

98

99

100

101

102

103

104

105

106

107

108

109

110

111

112

113

114

deciduous species, characterized by toothed or lobed leaves with pointed tips or cusps, long linear or broad, recurved cupule scales (Menitsky 2005). Quercus trojana is typically small, semievergreen tree, easily identified by its subcoriaceous, elongated, glabrous and regularly dentate leaves, and by the acorn enclosed in a characteristic thick and woody dome, covered with elongated, pubescent scales (Zielinski et al. 2006). Its distribution range extends from western and southern Anatolia through Turkey, southwest Bulgaria, Greece and the Aegean region, up to the Balkans (Croatia, Serbia, Bosnia, Montenegro, Albania, Macedonia), with few disjunct outposts in south-eastern Italy (Browicz 1982; Jalas and Suominen 1976). Q.trojana is a thermo-mesophilous species which prefers dry, predominantly limestone neutral to sub-acid soils. It, however, can adapt to all kinds of edaphic conditions (Menitsky 2005, Giardina et al. 2014) forming pure and mixed supra-Mediterranean, occasionally meso-Mediterranean, forests and sporadically participating to maquis formations under more xerophytic conditions. It can also grow on very dry/extreme habitats (e.g. karst areas) and for this reason it is recommended for reforestation/afforestation of extremely poor/degraded sub-Mediterranean habitats (Ballian et al. 2014). European Q. trojana woods have been designated as special areas for conservation (Habitat Directive 92/43/EEC; Annex I, Code 9250); their habitats are generally considered in a situation where a change in management or policy is required to return to a favorable status.

In Italy, its current distribution is restricted to southern regions (Apulia and Basilicata) and is a remnant of a once more widely-spread range which has been severely reduced by intensive human exploitation (Schirone and Spada 1995; Misano and Di Pietro 2007). Deforestation for agricultural purposes and the good technological properties of its wood are the main causes of the decrease in Q. trojana occurrence in Italy. The increasing human impact over the last century has led to a highly differentiated and fragmented landscape, consisting of the alternation of cultivated fields, patches of forest remains, farms and urban centers (Bottalico et al. 2006). The consequent habitat loss and deterioration, along with the changes in the accelerating dynamics of global and climatic 
115 changes have resulted in a strong reduction in the $Q$. trojana populations size, isolation and a 116 probable severe loss of their genetic diversity.

117 We investigated the genetic diversity and structure of the current $Q$. trojana populations in southern 118 Italy by means of microsatellites (SSRs). These markers are widely used to characterize the genetic 119 variation of long-lived species (Vendramin et al. 2004) and many studies highlight the use of them 120 as tool for identifying populations or areas for conservation (Smulders et al. 2008; Pautasso 2009; 121 Allendorf et al. 2010; van Zonneveld et al 2012; Lusini et al. 2014; Chiocchini et al. 2016).

122 The aims of this work were (1) to estimate the main genetic parameters for evaluating populations 123 genetic diversity and divergence, (2) to identify valuable areas/reservoirs of genetic diversity and 124 (3) to provide guidelines for conservation. Finally, we examined the genetic relationships among 125 the investigated stands and various eastern Mediterranean $Q$. trojana samples in order to speculate 126 on the origins of the Italian populations.

127 To the best of our knowledge, this is the first study on the genetic diversity and structure of $Q$. 128 trojana populations in Italy (and across the species range) based on the use of microsatellite markers. To date, this species has been studied only through purely ecological (Manicone 2007) or

130 historical surveys (Bottalico et al. 2006). Our intention is to contribute to increase the knowledge 131 and the preservation of $Q$. trojana in Italy, thereby promoting the sustainable management of the 132 genetic resources of the still poorly-known Mediterranean forest ecosystems.

\section{Material and Methods}

\section{$134 \quad$ Plant Material}

135 A total of 322 georeferenced samples from 17 sites located in south Italy were collected (Fig.1, 136 Table1). Sixteen sites were located in two different areas of Apulia region (National Park of Alta 137 Murgia and Martina Franca), where Q. trojana is represented by small groups of trees with a 138 scattered distribution or in mixed forests. The last site was located in Sicily (Riserva Naturale 139 Orientata "Bosco della Ficuzza"), and includes a recently identified population of unknown origin 140 (Giardina et al. 2014). The distance between each sampled tree was around 30-50 m. Moreover, to 
141 have a preliminary indication on the genetic similarity of the Italian populations with the eastern

142 Mediterranean $Q$. trojana germplasm, we also genotyped 23 samples of $Q$. trojana from Greece and

143 Turkey, kindly provided by Drs. T. Denk and G.W. Grimm (Table 2).

144 DNA Extraction and SSR analysis

145 Total genomic DNA was isolated by grinding $20 \mathrm{mg}$ of fresh leaf tissue and purified using the 146 Dneasy96 Plant Kit (Qiagen) according to the manufacturer's instructions. A set of six nuclear 147 microsatellite primers (QpZAG110, QpZAG7, QrZAG11, CsCAT1, CsCAT2 and CsCAT14) 148 developed in Quercus petraea and Q. robur (Steinkellner et al. 1997) and Castanea sativa 149 (Marinoni et al. 2003) were selected and used for the multiplex PCR analysis. These markers were 150 mapped on two F1 intraspecific crosses of $C$. sativa and $Q$. robur and each selected locus has been 151 shown to belong to a different linkage group (Casasoli et al. 2004; Barreneche et al. 2004). The 152 forward primer of each pair was labelled with one fluorescent dye (6-FAM, NED or VIC) (Table 3). 153 The PCR multiplex reaction was performed using the Type-it Microsatellite PCR Kit (QIAGEN, 154 Hilden, Germany) in $20 \mu \mathrm{L}$ total volume containing $20 \mathrm{ng}$ of genomic DNA. Cycling parameters 155 were: $5 \mathrm{~min}$ at $95^{\circ} \mathrm{C}, 28$ cycles for $30 \mathrm{~s}$ at $95^{\circ} \mathrm{C}, 90 \mathrm{~s}$ at $57^{\circ} \mathrm{C}$ and $30 \mathrm{~s}$ at $72{ }^{\circ} \mathrm{C}$, and a final step of $15630 \mathrm{~min}$ at $60{ }^{\circ} \mathrm{C}$. Amplification products $(1 \mu \mathrm{L})$ were added to $9.75 \mu \mathrm{L}$ formammide and $0.25 \mu \mathrm{L}$ 157 Genescan-500 LIZ and denatured at $95^{\circ} \mathrm{C}$ for $5 \mathrm{~min}$. The samples were run on an ABI PRISM 3130 158 Avant DNA sequencer. The alleles were scored using GeneMapper software (Life Technologies).

159 Data analysis

160 Genetic diversity indices

161 A set of intra and inter population genetic diversity parameters were calculated using the software 162 GeneAlEx 6.4.1 (Peakall and Smouse 2005). The observed (Na) and effective (Ne) number of 163 alleles, the observed (Ho) and expected (He) heterozygosity and Shannon diversity index (I) were 164 all calculated at each locus, over all loci and for each population. For each population were also 165 calculated the expected heterozygosity weighted on the number of samples (UHe) and the mean 166 number of private alleles (NPA). The fixation index Fis (Weir and Cockerham 1984) was computed 
167 for each locus across all populations and for each population over all loci using Arlequin 3.11

168 software (Excoffier et al. 2005). The statistical significance was tested with a non-parametric

169 approach described in Excoffier et al. (1992) with 1,000 permutations.

170 Because the presence of null alleles can affect the estimation of population differentiation, null

171 allele frequencies were estimated for each locus and population following the Expectation 172 Maximization (EM) algorithm of Dempster et al. (1977), implemented in FreeNA software 173 (Chapuis and Estoup 2007). Fst was estimated considering the presence of null alleles (EM-ENA 174 procedure) or excluding this procedure (without EM- ENA procedure).

175 The estimation of the mean number of alleles per locus as a measure of allelic richness (Ar) can be 176 affected by differences in sample size. For this reason, allelic richness and the private alleles 177 richness (PAr) were calculated by the statistical technique of rarefaction method implemented in 178 HP-Rare 1.1 (Kalinowski 2005). This approach uses the frequencies of alleles at locus to estimate 179 the expected number of alleles and/or private alleles in a subsample of $\mathrm{N}$ individuals selected at 180 random from sample of $\mathrm{N}$ individuals in each population.

181 Population structure analysis

182 Three different complementary approaches were used to characterise the patterns of genetic 183 structure of Italian Q. trojana populations.

184 1) Principal coordinates analysis (PCoA) based on a dissimilarity matrix of Nei's genetic distance 185 (Nei 1973) was performed using the software GeneAlEx 6.4.1 (Peakall and Smouse 2005).

186 2) Spatial Analysis of Molecular Variance (SAMOVA) was applied to delineate groups using 187 SAMOVA 1.0 software. We tested K from 2 to 16 (number of Quercus populations -1) selecting 188100 random starting conditions. We examined patterns of variation among groups $\left(\mathrm{F}_{\mathrm{CT}}\right)$ and within 189 groups $\left(\mathrm{F}_{\mathrm{SC}}\right)$ for each $\mathrm{K}$ to determine the most appropriate number of populations groups. The 190 configuration with the highest $\mathrm{F}_{\mathrm{CT}}$ was retained the best partition of Quercus populations.

191 3) A Bayesian approach implemented in the software STRUCTURE 2.3.4. (Prichard et al. 2000) 192 was performed. This method attempts to reveal the population structure by placing individuals or 
193 predefined groups in K number of clusters in order to minimize within-group linkage disequilibrium

194 and deviation from the Hardy-Weinberg equilibrium. The analysis was performed using the

195 admixture model on the whole dataset, with no previous population information, and the correlated

196 allele frequencies between population options (Falush et al. 2007). In this study, the range of 197 possible number of clusters (K) tested was from 1 to 19 (the putative number of populations plus 2).

198 Based on the initial results, a series of six independent runs were performed for $\mathrm{K}$ between 1 and 6 199 with a burn-in period of $10^{\prime} 000$ steps followed by $10^{5} \mathrm{MCMC}$ replicates. The ad-hoc statistic $\Delta \mathrm{K}$ 200 defined by Evanno et al. (2005) was used to detect the most likely number of cluster. This value is 201 based on the rate of change of the second order of $L(K)$ between two successive values of $K$ for six 202 replicates. The six runs from the most probable number of clusters were averaged by applying a 203 FullSearch algorithm provided by CLUMPP 1.1.2 (Jakobsson and Rosenberg 2007) and represented 204 graphically with DISTRUCT (Rosenberg 2004).

205 Hierarchical AMOVA (Excoffier et al. 2005) implemented by the software Arlequin 3.11, was 206 calculated considering the main groups obtained from the STRUCTURE and PcoA analysis. The 207 statistical significance was tested using a non-parametric approach described in Excoffier et al. 208 (1992) with 1,000 permutations.

209 We also tested for isolation by distance (IBD) performing correlation between genetic and 210 geographic distances using nonparametric pairwise simple and partial Mantel tests (Mantel 1967; 211 Smouse et al.1986). Assuming a nonlinear distribution of sampling sites, we regressed Slatkin's 212 linearized $\left[F_{\mathrm{ST}} /\left(1-F_{\mathrm{ST}}\right)\right]$ pairwise values against the corresponding natural logarithm of 213 geographic distances (straight-line distances in $\mathrm{Km}$ ).

214 Comparison of Italian and eastern Mediterranean Q. trojana samples

215 The genetic similarity among the Italian populations and Greek and Turkish samples were tested 216 performing a Principal Coordinates Analysis (PCoA) based on a dissimilarity matrix of Nei (Nei 217 1973) implemented by the software GeneAlEx 6.4.1 (Peakall and Smouse 2005). The samples from 218 Turkey and Greece were grouped considering their geographic location, as indicated in Table 2. 


\section{Results}

\section{Genetic diversity}

222 The six SSR loci assayed were all polymorphic and the number of alleles detected for each locus varied between 2.59 (QrZAG11) and 13.41 (QpZAG110) (Table 3). These two loci also showed the lowest (0.40) and the highest (0.88) expected heterozygosity (He), respectively. The observed heterozygosity (Ho) ranged from 0.17 (QrZAG11) to 0.92 in QpZAG7. The fixation index (Fis) showed positive and significant values in QrZAG11 and CsCAT1 loci (0.59 and 0.47 respectively).

Table 4 shows genetic diversity parameters for each population. The average effective number of alleles (Ne) was 5.41, ranging from 3.69 in MAC population to 6.91 in SOR population. The analysis conducted with FREENA software indicated the absence of null alleles (Fst using EMENA procedure $=0.034357 ;$ Fst not using EM-ENA procedure $=0.036697)$. The lowest observed with a mean value of 0.61 . The He ranged from 0.59 in the TM population to 0.76 in GIU and LOC

233 populations. These values are comparable with unbiased expected heterozygosity (UHe) values 234 indicating no effect due to the imbalance on the sampling size. The fixation index deviated significantly from zero in four populations (LOC, COL, PAL and SOR). Private alleles richness (PAr) values, calculated with the rarefaction method, ranged from 0.00 (GAL) to 0.45 (PARA), while allelic richness (Ar) values ranged from 5.72 (TM) to 9.10 (SOR).

Population structure

The Principal Coordinates Analysis (PCoA) (Fig. 2) based on Nei's unbiased genetic distance matrix (Table 6) suggested the presence of a non-random association of populations. The combined 241 first two axes explained $48.31 \%$ of the variation. Although the genetic distance was not high, two main groups could be distinguished. The first group includes populations sampled in the Martina

243 Franca area (COL, CRO, GAL, MAN, PAL, PAP, PIA, PRE, SOR and VER) as well as population 244 TM, located inside the National Park of Alta Murgia. A low genetic distance was found between 
245 these populations (Table 6). The second group (with respect to the second axis) includes two 246 populations bordering the National Park of Alta Murgia (PARA, GIU), a population sampled in the 247 Martina Franca area (LOC) and a population bordering the Martina Franca area, located between 248 this area and the National Park (SAN). Finally, the MAC population, located in the inner part of the 249 National Park, was genetically distant from all the other populations from Apulia. The Sicilian 250 population (SIC) was not included in either of the two main groups.

251 SAMOVA results indicated $\mathrm{K}=2$ as the most appropriate number of populations groups (Fsc= $2520.02197, \mathrm{~F}_{\mathrm{CT}}=0.05543, \mathrm{P}<0.001$ see Supplementary Table S1). Considering the grouping based on $253 \mathrm{~K}=2$, all the populations except MAC were included in the same gene pool.

254 The subsequent STRUCTURE analysis corroborate the SAMOVA and PCoA results and provided 255 additional information on the level of genomic admixture among populations (Fig. 3).

256 The most probable division with the strongest support in terms of log-likelihood values was 257 detected at $\mathrm{K}=4$ (Fig.3 A). The MAC population was assigned to cluster I (blue) as well as SIC; 258 cluster II (red) grouped together the neighbouring populations of the National Park of Alta Murgia 259 (GIU, PARA, SAN, and LOC), which had already been identified as a distinct group in the analysis 260 of principal coordinates. The populations in Martina Franca area displayed a high degree of 261 admixture of the four clusters with the prevalence of clusters III and IV (green and yellow) (Fig. 3 262 B and C).

263 The hierarchical AMOVA was carried out according to the three main gene pools obtained with the 264 PCoA and STRUCTURE analysis. All the populations from Martina Franca area were grouped 265 together while the other two groups correspond to the STRUCTURE cluster I and cluster II 266 respectively. The molecular variance among groups inferred was $2.24 \%(\mathrm{P}<0.01)$. The majority of 267 molecular variance was partitioned within individuals $(94.96 \% \mathrm{P}<0.01)$ (Tab.5).

268 The pairwise linearized genetic differentiation values $\left[F_{\mathrm{ST}} /\left(1-F_{\mathrm{ST}}\right)\right]$ and the natural logarithm of 269 geographic distances among sampling sites were not significantly correlated (Mantel test $r=0.128$, $270 \quad P=0.113)$. 
271 Comparison of Italian and eastern Mediterranean Q. trojana samples Fig. 4 shows the Principal 272 Coordinates Analysis performed to test the genetic similarity of the Italian in relation to the Greek 273 and Turkish samples. The combined first two axes explained $63.84 \%$ of the variation. This analysis 274 confirmed the population subdivision of the Italian germplasm recorded in Fig. 3 and, further 275 highlighted a genetic similarity among the populations of the Martina Franca area and the samples 276 from Greece. The SAN, PARA, GIU and LOC populations, and the MAC and the Sicilian 277 population formed gradually less related groups, whereas the Anatolian samples (North-western, 278 Central-western- and South-western Turkey) displayed a higher genetic distance from all the other 279 (Italian and Greek) Q. trojana populations.

\section{Discussion}

\section{Genetic Diversity}

282 To the best of our knowledge, this is the first report on the genetic diversity and structure of $Q$. 283 trojana populations in Italy, as well as all across the species current range. Our results thus provide 284 the first insight into the potential of this species to adapt to environmental changes and could serve 285 as a benchmark for future management and conservation policies on genetic resources.

286 Our data set exhibited high levels of genetic diversity at the SSR loci examined. However, two SSR markers (QrZAG11 and CsCAT1) showed a positive and significant fixation index. A possible interpretation for the allelic frequencies that deviate from equilibria involves hitchhiking effects between SSR loci and various adaptive traits. The allele fixation might have been favoured by selection and variability reductions in neighbouring genome areas as a well-recognized result of 291 directional selection for a specific adaptive trait (Andolfatto 2001). Allele fixation can also be the 292 result of genetic drift. However, diversity reductions due to genetic drift would affect the genome 293 rather uniformly (Alberto et al. 2010), which is not the case with the other SSR loci examined. Indeed, more extended SSR investigations are required to clarify this point and to assign a selective response of these two loci. High values of allelic richness, of heterozygosity and of Shannon index

296 were generally observed in our dataset. These results are in agreement with those observed in other 
Quercus species in Italy (Antonecchia el al. 2015), France (Alberto et al. 2010), Germany, Greece

298 and Turkey (Alberto et al. 2013), thus highlighting the overall good conditions of the Italian

299 populations of $Q$. trojana in terms of gene diversity. The fixation indices obtained for the 300 populations were significantly positive only for LOC, COL, PAL and SOR populations. This 301 indicates that the Italian populations are largely outbreeding, with only minor levels of inbreeding. 302 Quercus species are generally wind-pollinated. Outcrossing rates are expected to be high for wind303 pollinated tree species, whereas the positive and significant inbreeding coefficient detected in some 304 populations revealed instances of biparental inbreeding (i.e. inbreeding among genetically related 305 trees). In contrast, the MAC population showed a highly negative value. Although statistically not 306 supported, this result could be due to different causes, such as the fusion of formerly isolated populations or adaptive advantage of heterozygote individuals.

\section{Population structure}

The PCoA, SAMOVA and STRUCTURE analysis enable us to group the 17 natural populations into three main different gene pools. A little genetic differentiation among populations was observed while the greatest percentage of molecular variation was found within individuals. These results are in accordance with findings in other Quercus Italian populations (Bruschi et al. 2003). The formation of these different gene pools may be the result of the increasing fragmentation and isolation of the populations of $Q$. trojana in Apulia due to the massive land use changes over time. This may have altered the gene flow among populations that previously formed a more homogeneous gene pool, and led to the selection of characteristic gene pools within the stands. In 318 agreement, with this, the populations in the Martina Franca area, located within continuous forests, appear to have no barriers to gene flow. Further explanations for the different gene pools include the selective dispersal of seeds from different sources, which could have originated naturally or by man. The effect of human pressure on current population structure could be confirmed by the lack 322 of significant correlation observed between geographical and genetic distances. This study showed 
323 that the population SIC is genetically similar to the Apulian populations, especially to MAC. We 324 can therefore assume that the $Q$. trojana population recently (and unexpectedly) discovered in the 325 'Bosco della Ficuzza' Natural Reserve may have a common origin with the Apulian populations.

326 The species could have been introduced into Sicily quite recently, most probably in the last century. 327 However, in agreement with Giardina et al. (2014) we can't totally exclude the natural origins of 328 this population due to the occurrence in the same area of many other deciduous trees relating to 329 chorotype southeastern European sensu latu (Celtis tournefortii Lam, Fraxinus ornus L. Ostrya 330 carpinifolia Scop, Quercus cerris L., Q. dalechampii Ten, Sorbus aria L.).

331 Finally, our data provide preliminary insights regarding the origin of the Apulian populations of $Q$. 332 trojana. Although the number of east Mediterranean samples used for the comparison was limited, 333 the PCoA analysis showed a clear separation between the Anatolian and the Italian samples. 334 Conversely, a lower genetic distance between the Greek samples and the Italian data set was 335 evident. In particular, the Greek samples clustered together with the populations of the Martina 336 Franca area. Such a strong genetic similarity could suggest a common origin for the Greek and the 337 Italian gene pools, and Martina Franca appears to be the area that is most directly linked to the 338 Greek germ-plasm. Man-mediated seed exchanges might have eventually occurred during the 339 Greek settlement in southern Italy in the 8th century BC. In this case, populations of Martina Franca would likely have descended from the original Greek seed stock and acted as sources for the rest of 341 the Apulian range. If this was the case, all other Apulian populations probably originated from seed 342 lots harvested in a way that altered the original allele frequencies, or from slightly different Greek 343 seed sources. Nevertheless, it is now widely acknowledged that the occurrence of $Q$. trojana in 344 Apulia is a part of a framework of several plant taxa belonging to an east Mediterranean vegetation 345 type (e.g., Q. ithaburensis subsp. macrolepis (Kotschy) Hedge \& Yalt, Periploca graeca L., Salvia 346 triloba L., Phlomis fruticosa L.) all recognized as the "Apulian paleo-Aegean stock" (Francini Corti 347 1966). In addition, a close phylogeographic relationship between the two regions on both sides of 348 the Adriatic Sea has been detected in other oak species, such as Q. frainetto (Fineschi et al. 2002), 
Q. ilex (Lumaret et al., 2002), Q. coccifera (Lopez de Heredia et al., 2007) and Q. cerris (Bagnoli et al. 2016), and herbaceous taxa (e.g. Musacchio et al. 2008; Hilpold et al. 2014). In fact, land

351 connections during the Messinian salinity crisis and/or eustatic sea-level shifts creating land bridges

352 during the Pleistocene glaciations allowed biotic exchanges between the Balkans and south-eastern 353 Italy (Nieto Feliner 2014). Our data would be therefore consistent with the Apulian populations of $354 Q$. trojana as the remnants either of a once continuous ancestral range or of a colonization wave 355 that moved westward from the Balkan range in more recent times. Clearly, additional data from the 356 near-by west Balkan region (e.g. Croatia, Albania, Montenegro) and from the cradle of the Cerris 357 group (the Aegean area; Denk and Grimm 2010) will help in precisely defining the origin of this 358 important oak in Italy.

359 Implications for conservation

360 The analysis of genetic variation within and between populations of a species can help in 361 highlighting the historical processes behind the genetic diversity (Dumolin-Lapegue et al. 1997) and 362 providing useful information to establish adequate programs for the conservation of genetic 363 resources. A high levels of genetic variation are expected to increase the potential of the species to 364 respond to selective pressure (Kalinowski 2004). It is essential, therefore, to identify the 365 populations and areas that show high values of genetic diversity and divergence so as to identify which populations merit the most attention in terms of conservation priority (Petit et al. 1997; 367 Ollivier and Foulley 2013). Populations showing characteristic gene pools are also considered as 368 valuable source material for genetic conservation programs, thus the populations structure analysis 369 provides complementary indications as to the intra population genetic diversity.

370 The highest allelic richness and genetic diversity were scored by the GIU, LOC, PARA, MAN, 371 PAL, SAN and SOR populations. However, the high fixation indexes evidenced by LOC, PAL and 372 SOR would suggest the better use of GIU, PARA, MAN and SAN for an efficient conservation of 373 the species gene diversity and as germplasm reservoir for afforestation and reforestation programs 374 in Apulia. The GIU population is included in the National Park, thus benefitting from all the related 
management regimes (e.g. sustainable silviculture). PARA, MAN and SAN showed a high number of private alleles, indicating some kind of isolation, which is confirmed by the large amount of cultivated lands surrounding these two populations. These populations also span most of the distribution of Q. trojana in Apulia, connecting the two main areas of the species (National Park of Alta Murgia and Martina Franca area). A reduction in their isolation and a re-establishment of the gene flow via ecological connections with the near-by forest patches (e.g. with tree plantations in abandoned open spaces and private farms) would greatly contribute to maintaining high values of $\mathrm{Ar}$ and $\mathrm{He}$ for the whole species in the region. However, the high inbreeding coefficient displayed by SOR, PAL and LOC needs to be investigated. The possible causes of inbreeding in these populations should be addressed by evaluating both demographic (age of the trees and silviculture regime, which both affecting the number of reproductive individuals) and ecological factors (biotic and abiotic disturbances). Inter- and intra-population gene flow should then be restored, and the next generations should be evaluated relative to their Fis and He. In order to preserve all the genetic diversity identified in this study, the MAC population in Apulia certainly deserves further attention. This population showing, a highly negative Fis and the highest mean number of private alleles resulted the most divergent. This might be indicative of an origin from different seed sources and /or adaptive advantage of the heterozygote individuals.

The TM population located in the inner part of the National Park showed the lowest gene diversity values suggesting that germ plasm belonging to the same genetic cluster (e.g. MAN) should be reintroduced into this population. The current management regimes should be maintained to preserve the Sicilian population (SIC) but more extensive research should be conducted to clarify its origin (La Mantia and Pasta, 2005).

\section{Concluding remarks}

This study can be taken as an example of how to apply marker based genetic tools in conservation programs for a marginal Mediterranean forest species with highly fragmented distribution. 
400 The evaluation of genetic diversity, genetic structure and gene flow of Italian $Q$. trojana 401 populations allowed: 1) to identify priorities for $Q$. trojana conservation in southern Italy and 2) to 402 propose possible measures to counteract stand fragmentation, isolation and inbreeding.

403 Besides the genetic inputs provided, complementary actions can be suggested such as the 404 preservation of the natural habitat, the ecological connection among residual forest patches and the 405 control of related biotic stress factors (pest, pathogens and alien species). In addition, appropriate 406 conservation programs for Italian Q. trojana could greatly benefit from a more extensive 407 knowledge of the species genetic resources available along the whole distribution range (Balkan 408 region).

409

410 ACKNOWLEDGEMENTS The authors wish to acknowledge Dr. P. Pollegioni for her critical 411 discussion of the results, Prof. G. Scarascia Mugnozza to encourage this research and G. Giardina 412 and S. Pasta for their help in collecting Sicilian population of Quercus trojana. This research was 413 funded by the National Park of Alta Murgia and the Apulia Region. 


\section{References}

Alberto, F., Niort, J., Derory, J., Lepais, O., Vitalis, R., Galop, D., Kremer, A. 2010. Population differentiation of sessile oak at the altitudinal front of migration in the French Pirenees. Mol. Ecol. 19: 2626-2639.

Alberto, J.F., Deroroy, J., Boury, C., Frigerio, J.M., Zimmermann, N.E., Kremer, A. 2013. Imprints of natural selection along environmental gradients in phenology-related genes of Quercus petraea. Genetics 195: 495-512.

Alfaro, R.I., Fady, B., Vendramin, G.G., Dawson, I.K., Fleming, R.A., Sáenz-Romero, C., Lindig-Cisneros, R.A., Murdock, T., Vinceti, B., Navarro, C.M., Skrøppa, T., Baldinelli, G., ElKassaby, Y.A., Loo J. 2014. The role of forest genetic resources in responding to biotic and abiotic factors in the context of anthropogenic climate change. Forest. Ecol. Manag. 333: 76-87.

Allendorf, F.W., Hohenlohe, P.A., Luikart, G. 2010. Genomics and the future of conservation genetics. Nat. Rev. Genet. 11: 697-709.

Andolfatto, P. 2001. Adaptive hitchhiking effects on genome variability. Curr. Opin. Genet. Dev. 11: 635-641.

Antonecchia, G., Fortini, P., Lepais, O., Gerber, S., Léger, P., Scippa, G.S., Viscosi, V. 2015. Genetic structure of a natural oak community in central Italy: evidence of gene flow between three sympatric white oak species (Quercus, Fagaceae). Ann. For. Res. 58 (2): 205-216.

Bagnoli, F., Tsuda, Y., Fineschi, S., Bruschi, P., Magri, D., Zehlev, P., Paule, L., Simeone, M.C., González-Martínez, S.C., Vendramin, G.G. 2016. Combining molecular and fossil data to infer demographic history of Quercus cerris: insights on European eastern glacial refugia. J. Biogeogr. 43: 679-690.

Ballian, D., Hajrudinović, A., Francić, J., Bogunić , F. 2014. Morphological variability of the leaves of the Macedonian oak (Quercus trojana Webb.) in Bosnia Herzegovina and Montenegro. Šumarski list 3-4: 135-144 
Barreneche, T., Casasoli, M., Russell, K., Akkak, A., Meddour, H., Plomion, C., Kremer, A. 2004. Comparative mapping between Quercus and Castanea using simple sequence repeats (SSRs). Theor. Appl. Genet. 108: 558-566.

Bossdorf, O., Auge, H., Lafuma, L., Rogers, W., Siemann, E., Prati, D. 2005. Phenotypic and genetic differentiation between native and introduced plant populations. Oecologia 144: 1-11.

Bottalico, F., Sanesi, G., Lafortezza, R. 2006. Le formazioni boschive a prevalenza di Quercus trojana Webb. nel comune di Putignano (BA). ANNALI A.I.S.F. Vol. LV, 2006: 79-95.

Browicz, K. 1982. Chorology of trees and shrubs in south-west Asia and adjacent regions 1. Warszawa \& Poznao

Bruschi, P., Vendramin, G.G., Bussotti, F., Grossoni, P. 2003. Morphological and molecular diversity among Italian populations of Quercus petraea (Fagaceae). Ann. Bot-London 91: 707-716.

Casasoli, M., Pot, D., Plomion, C., Monteverdi, M.C., Barreneche, T., Lauteri, M., Villani, F. 2004. Identification of QTLs affecting adaptive traits in Castanea sativa Mill. Plant. Cell. Environ. 27: 1088-1101.

Chapuis, M.P., and Estoup A. 2007. Microsatellite null alleles and estimation of population differentiation. Mol. Biol. Evol. 24: 621-631.

Chiocchini, F., Mattioni, C., Pollegioni, P., Lusini, I., Martín, M.A., Cherubini, M., Lauteri, M. and Villani,F. 2016. Mapping the Genetic Diversity of Castanea sativa: Exploiting Spatial Analysis for Biogeography and Conservation Studies. J. Geogr Inf. Syst.

\section{8: $248-259$.}

Dempster, A.P., Laird, N.M., Rubin, D.B. 1977. Maximum likehood from incomplete data via the EM algorithm. J. Roy. Stat. Soc. B. Met. 39:1-38

Denk, T., and Grimm, G.W. 2010. The oaks of western Eurasia: traditional classifications and evidence from two nuclear markers. Taxon 59: 351-366.

Dumolin-Lapegue, S., Demesure, B., Fineschi, S., Le Corre, V., Petit, R.J. 1997. Phylogeographic structure of white oaks throught out the European continent. Genetics 146: 1475- 
1487.

Eckert, C.G., Samis, E., Lougheed, S.C. 2008. Genetic variation across species' geographical ranges: the central-marginal hypothesis and beyond. Mol Ecol 17:1170 -1188.

Evanno, G., Regnaut, S., Goudet, J. 2005. Detecting the number of clusters of individuals using the software STRUCTURE: a simulation study. Mol. Ecol. 14: 2611-2620.

Excoffier, L., Smouse, P.E., Quattro, J.M. 1992. Analysis of molecular variance from metric distance among DNA haplotypes: application to human mitochondrial DNA restriction data. Genetics 131: 479-491.

Excoffier L, Laval G, Schneider S (2005) Arlequin (version 3.0): an integrated software package for population genetics data analysis. Evolutionary Bioinformatics Online 1:47-50

Fineschi, S., Taurchini, D., Grossoni, P., Petit, R.J., Vendramin, G.G. 2002. Chloroplast DNA variation of white oaks in Italy. Forest. Ecol. Manag. 156: 103-114.

Francini Corti, E. 1966. Aspetti della vegetazione pugliese e contingente paleoegeico meridionale della Puglia. Annali Accademia Italiana di Scienze Forestali 15: 137-194.

Falush, D., Stephens, M., Pritchard, J.K. 2007. Inference of population structure using multilocus genotype data: dominant markers and null alleles. Mol. Ecol. Notes 7: 574-578.

Gapare, W.J. 2014. Merging applied gene conservation activities with advanced generation breeding initiatives: a case of study of Pinus radiate D. Don. New. Forest 45: 311-331.

Geburek, T., and Konrad, H. 2008. Why the conservation of forest genetic resources has not worked. Conserv. Biol. 22(2): 267-274.

Giardina, G., La Mantia, T., Sala, G., Di Leo, C., Pasta, S. 2014. Possibile origine e consistenza di un popolamento di Quercus trojana Webb. Subsp. Trojana (Fagaceae) nel Bosco della Ficuzza (Palermo, Sicilia). Naturalista sicil. S. IV, XXXVIII pp.265-289.

Hilpold, A., Vilatersana, R., Susanna, A., Meseguer, A.S., Boršic', I., Constantinidis, T., Filigheddu, R., Romaschenko, K., Suárez-Santiago, V.N., Tugay, O., Uysal, T., Pfeil, B.E., Garcia- 
Jacas, N. 2014. Phylogeny of the Centaurea group (Centaurea, Compositae) - Geography is a better predictor than morphology. Mol. Phylogenet. Evol. 77: 195-215.

Honnay, O., Jacquemyn, H. 2007. Susceptibility of common and rare plant species to the genetic consequences of habitat fragmentation. Conserv. Biol. 21: 823-831.

Hubert, F., Grimm, G.W., Jousselin, E., Berry, V., Franc, A., Kremer, A. 2014. Multiple nuclear genes stabilize the phylogenetic backbone of the genus Quercus. Syst. Biodivers. 12: 405423.

Jakobsson, M., and Rosenberg, N.A. 2007. CLUMPP: a cluster matching and permutation program for dealing with label switching and multimodality in analysis of population structure. Bioinformatics 23: 1801-1806.

Jalas, J., and Suominen, J. 1976. Atlas Florae Europeae 3. Helsinki.

Kalinowski, S.T. 2004. Counting alleles with rarefaction: Private alleles and hierarchical sampling designs Conserv. Genet. 5: 539-543.

Kalinowski, S.T. 2005. HP-Rare: a computer program for performing rarefaction on measures of allelic diversity. Mol. Ecol. Notes 5: 187-189.

La Mantia, and T., Pasta, S. 2005. The Sicilian phanerophytes: still a noteworthy patrimony, soon a lost resource? In Proceedings of IUFRO Conference 15 November 2003, Firenze. Monitoring and indicators of forest biodiversity in Europe - from ideas to operationality. Edited by Marco Marchetti EFI n.51: 515-526.

López de Heredia, U., Jiménez, P., Collada, C., Simeone, M.C., Bellarosa, R., Schirone, B., Cervera, M.T., Gil, L. 2007. Multi-marker phylogeny of three evergreen oaks reveals vicariant patterns in the Western Mediterranean. Taxon 56: 1209-1209.

Lumaret, R., Mir, C., Michaux, H., Raynal, V. 2002. Phylogeographic variation of chloroplast DNA in holm oak (Q. ilex L.). Mol. Ecol. 11: 2327-2336. 
Lusini, I., Velichkov, I., Pollegioni, P., et al. 2014. Estimating the genetic diversity and spatial structure of Bulgarian Castanea sativa populations by SSRs: implication for conservation. Conserv Genet 15: 283-293

Manicone, R.P. 2007. Degrado e biodiversità nel bosco di Lucignano della Murgia Materana. Silvae Anno III n.9 pp.233-249.

Mantel, N. 1967. The detection of disease clustering and a generalized regression approach. Cancer Res 27:209-220

Marinoni, D., Akkak, A., Bounous, G., Edwards, K.J., Botta, R. 2003. Development and characterization of microsatellite markers in Castanea sativa (Mill.). Mol. Breeding 11: 127-136.

Menitsky, Yu. L. 2005. Oak of Asia. Science Publishers Plymouth, UK.

Misano, G., and DiPietro, R. 2007. Habitat 9250 "Quercus trojana woods" in Italy. Fitosociologia vol. 44 (2) suppl. 1: 235-238.

Musacchio, A., Pellegrino, G., Cafasso, D., Widmer, A., Cozzolino, S. 2006. A unique A. palustris lineage across the Otranto strait: botanical evidence for a past land-bridge? Plant Syst. Evol. 262: 103-111.

Nei, M. 1973. Analysis of gene diversity in subdivided populations. Proc Natn Acad Sci U.S.A. 70: 3321-3323.

Nieto Feliner, G. 2014. Patterns and processes in plant phylogeography in the Mediterranean Basin. A review. Perspect. Plant. Ecol. Evol. Syst. 16: 265-278.

Oddou-Muratorio. S., Klein, E.K. 2008. Comparing direct vs. indirect estimates gene flow within a population of a scattered tree species. Mol. Ecol. 17: 2743-2754.

Ollivier, L., and Foulley, J.L. 2013. A note on the partitioning of allelic diversity. Conserv. Genet. 14: 1285-1290.

Pautasso, M. 2009. Geographical genetics and conservation of forest tree. Systematics. 11: 157-189.

Peakall, R., and Smouse, P.E. 2005. GeneAlex6: genetic analysis in excel. Population https://mc06.manuscripttcentral.com/cjfr-pubs 
genetic software or teaching and research. Australian National University, Canberra, Australia.

Petit, R.J., Pineau, E., Demesure, B., Bacilieri, R., Ducousso, A., Kremer, A. 1997. Chloroplast DNA footprints of postglacial recolonization by oaks. Proc. Natl. Acad. Sci. U.S.A 94: 9996-10001.

Pritchard, J., Stephens, M., Donnelly, P. 2000. Inference of population structure using multilocus genotype data Genetics 155: 945-959.

Reed, D.H., and Frankham, R. 2003. Correlation between fitness and genetic diversity. Conserv. Biol. 17: 230-237.Rosenberg, N.A. 2004. Distruct: a program for the graphical display of population structure. Mol. Ecol. Notes 4: 137-138.

Schirone, B., and Spada, F. 1995. Anomalies in reproductive phenology and vegetation history: The case of SE Italy. Colloques Phytosociologiques 16: 847-857.

Shachak, M., Boeken, B., Groner, E., Kadmon, R., Lubin, Y., Meron, E., Neeman, G., Perevolotsky, A., Shkedy, Y., Ungar, E.D. 2008. Woody species as landscape modulators and their effect on biodiversity patterns. Bioscience 58: 209-221.

Simeone, M.C., Piredda, R., Papini, A., Vessella, F., Schirone, B. 2013. Application of plastid and nuclear markers to DNA barcoding of Euro-Mediterranean oaks (Quercus, Fagaceae): problems, prospects and phylogenetic implications. Bot. J. Linn. Soc. 172: 478-499.

Smouse, P.E, Long, J.C., Sokal R.R. 1986. Multiple regression and correlation extensions of the Mantel test of matrix correspondence. Syst Zool 35: 627-632.

Smulders, M.J.M., Cottrell J.E., van der Shoot J. et al. 2008. Structure of the genetic diversity in black poplar (Populus nigra L.) populations across European river systems: consequences for conservation and restoration. Forest Ecol Manag 255: 1388-1399.

Steinkellner, H., Fluch, S., Turescher, E., Lexer, C., Streiff, R., Kremer, A., Burg, K., Glossl, J. 1997. Conservation of (GA/CT) microsatellite loci between Quercus petraea. Plant. Mol. Biol. 33: 1093-1196. 
Souto, C., Mathiasen, P., Acosta, M. 2015. Identifying Genetic Hotspots by Mapping Molecular Diversity of Widespread Trees: When Commonness Matters. J Hered. 106: 537-545

Vendramin, G.G., Scotti, I., Ziegenhagen, B. 2004. Microsatellites in forest tree species: characteristics, identification and application. Kumar S, Fladung M (eds) Molecular genetics and breeding of forest trees. Haworth Press, New York, p.429

Weir, B.S., and Cockerham, C.C. 1984. Estimating F-statistics for the analysis of populations structure. Evolution 38: 1358- 1370.Zielinski, J., Petrova, A., Tomaszewski, D. 2006. Quercus trojana subsp. yaltirikii (Fagaceae), a new subspecies from southern Turkey. Willdenowia 36: 845849 ISSN 0511-9618 BGBM Berlin-Dahle. 
Table 1. Sample ID, number of individuals (N), geographical location and coordinates for $17 Q$. trojana populations genotyped in this study.

\begin{tabular}{llllll}
\hline Population & ID & N & Location & Lat. & Long. \\
\hline Giustino & GIU & 14 & National Park (Apulia) & 40.841 & 16.744 \\
Lama Corriera & MAC & 25 & National Park (Apulia) & 40.892 & 16.537 \\
Parata & PARA & 13 & National Park (Apulia) & 40.771 & 16.748 \\
Trullo di Mezzo & TM & 20 & National Park (Apulia) & 45.358 & 16.042 \\
Locorotondo & LOC & 14 & Martina Franca (Apulia) & 40.755 & 17.326 \\
Santuario & SAN & 20 & Martina Franca (Apulia) & 40.798 & 17.041 \\
Colucci & COL & 20 & Martina Franca (Apulia) & 40.680 & 17.203 \\
Croce Grande & CRO & 19 & Martina Franca (Apulia) & 40.406 & 17.148 \\
Galeone & GAL & 20 & Martina Franca (Apulia) & 40.736 & 17.217 \\
Mangiato & MAN & 20 & Martina Franca (Apulia) & 40.744 & 17.262 \\
Palazzolo & PAL & 20 & Martina Franca (Apulia) & 40.712 & 17.223 \\
Papariello & PAP & 19 & Martina Franca (Apulia) & 40.670 & 17.420 \\
Bosco Pianelle & PIA & 19 & Martina Franca (Apulia) & 40.670 & 17.216 \\
Presidente & PRE & 20 & Martina Franca (Apulia) & 40.652 & 17.413 \\
Ciccio la Sorte & SOR & 17 & Martina Franca (Apulia) & 40.661 & 17.376 \\
Verdurizzo & VER & 20 & Martina Franca (Apulia) & 40.647 & 17.386 \\
Bosco della Ficuzza & SIC & 23 & Ficuzza (Sicily) & 37.875 & 13.407 \\
\hline
\end{tabular}


Table 2. Sample ID, geographical origin and voucher information for 23 specimens of Q. trojana from Greece and Turkey genotyped in this study

\begin{tabular}{llll}
\hline Sample ID & Origin & Geographical location & Voucher \\
\hline BAL-17 & Greece & Ioannina & Denk, Ruhri \& Ruhri 20081013/1-1 S \\
BAL-18 & & Ioannina & Denk, Ruhri \& Ruhri 20081013/1-2 S \\
BAL-19 & & Ioannina & Denk, Ruhri \& Ruhri 20081013/1-3 S \\
BAL-20 & & Ioannina & Denk, Ruhri \& Ruhri 20081013/1-4 S \\
BAL-21 & & Ioannina & Denk, Ruhri \& Ruhri 20081014/2-1 S \\
BAL-22 & & Ioannina & Denk, Ruhri \& Ruhri 20081014/2-2 S \\
BAL-23 & & Ioannina & Denk, Ruhri \& Ruhri 20081014/1-1 S \\
BAL-44 & North-Western Turkey & Ulubat Gölu & Denk \& Grimm 2006365 S \\
BAL-45 & & Ulubat Gölu & Denk \& Grimm 2006366 S \\
BAL-05 & Central-Western Turkey & Yeşildağ & Denk \& Grimm 2006278 S \\
BAL-06 & & Yukari Gökdere & Denk \& Grimm 2006305 S \\
BAL-07 & & Sirasli & Denk \& Grimm 2006344 S \\
BAL-36 & & Yeşildağ & Denk \& Grimm 2006284 S \\
BAL-37 & & Yukari Gökdere & Denk \& Grimm 2006304 S \\
BAL-39 & & Sirasi & Denk \& Grimm 2006337 S \\
BAL-42 & & Yessildağ & Denk \& Grimm 2006279 S \\
BAL-43 & & Sirasli & Denk \& Grimm 2006338 S \\
BAL-01 & South-Western Turkey & Ereğli & Denk \& Grimm 2006248 S \\
BAL-03 & & Ereğli & Denk \& Grimm 2006252 S \\
BAL-04 & & Madenşehri & Denk \& Grimm 2006271 S \\
BAL-35 & & Ereğli & Denk \& Grimm 2006254 S \\
BAL-40 & & Madenşehri & Denk \& Grimm 2006269 S \\
BAL-41 & & Madenşehri & Denk \& Grimm 2006270 S \\
\hline
\end{tabular}


Table 3. Range of alleles and dye of six microsatellite loci analyzed: number of alleles (Na), number of effective alleles (Ne), Shannon's index (I), expected heterozygosity (He), observed heterozygosity (Ho), within-population inbreeding coefficient (Fis)

\begin{tabular}{lllllllll}
\hline Locus & Dye & Range (bp) & Na & Ne & I & He & Ho & Fis \\
\hline QpZAG110 & FAM & $193-235$ & 13.41 & 8.84 & 2.34 & 0.88 & 0.80 & 0.09 \\
QpZAG7 & VIC & $115-153$ & 12.76 & 7.97 & 2.26 & 0.87 & 0.92 & -0.07 \\
QrZAG11 & FAM & $242-286$ & 2.59 & 1.78 & 0.67 & 0.40 & 0.17 & $0.59^{*}$ \\
CsCAT14 & FAM & $100-150$ & 8.65 & 4.93 & 1.78 & 0.78 & 0.79 & -0.02 \\
CsCAT2 & FAM & $200-250$ & 6.41 & 2.04 & 1.05 & 0.48 & 0.50 & -0.05 \\
CsCAT1 & NED & $160-199$ & 11.06 & 6.93 & 2.11 & 0.84 & 0.45 & $0.47^{*}$ \\
\hline
\end{tabular}

* Significance of inbreeding coefficient Fis was tested using a non-parametric approach described in Exoffier et al., (1992) with 1,000 permutations: * $\mathrm{p}<0.05$ 
Table 4. Genetic diversity parameters for the seventeen $Q$. trojana populations analyzed through six microsatellite loci: mean number of different alleles $(\mathrm{Na})$, mean number of effective alleles $(\mathrm{Ne})$, Shannon's index (I), observed heterozygosity (Ho), expected heterozygosity (He), unbiased expected heterozygosity (UHe), inbreeding coefficent (Fis), mean number of private alleles (NPA), allelic richness (Ar) and private allelic richness (PAr).

\begin{tabular}{lllllllllll}
\hline & Na & Ne & I & Ho & He & UHe & NPA & Ar & PAr & Fis \\
\hline GIU & 8.33 & 5.53 & 1.75 & 0.58 & 0.76 & 0.79 & 0.17 & 7.60 & 0.19 & 0.07 \\
LOC & 8.00 & 5.65 & 1.75 & 0.63 & 0.76 & 0.79 & 0.33 & 7.44 & 0.32 & $0.10^{*}$ \\
MAC & 8.17 & 3.69 & 1.47 & 0.62 & 0.65 & 0.67 & 0.67 & 6.02 & 0.39 & -0.14 \\
PARA & 9.17 & 5.71 & 1.79 & 0.64 & 0.74 & 0.77 & 0.50 & 8.49 & 0.45 & 0.02 \\
SAN & 10.50 & 5.99 & 1.82 & 0.60 & 0.74 & 0.76 & 0.50 & 8.15 & 0.30 & 0.04 \\
TM & 6.83 & 3.91 & 1.34 & 0.49 & 0.59 & 0.61 & 0.17 & 5.72 & 0.22 & 0.01 \\
COL & 9.83 & 5.56 & 1.72 & 0.56 & 0.69 & 0.71 & 0.33 & 7.86 & 0.34 & $0.10^{*}$ \\
CRO & 9.00 & 5.79 & 1.66 & 0.56 & 0.68 & 0.70 & 0.00 & 7.35 & 0.05 & 0.04 \\
GAL & 8.50 & 4.75 & 1.56 & 0.65 & 0.66 & 0.68 & 0.00 & 6.80 & 0.00 & -0.04 \\
MAN & 10.00 & 5.67 & 1.79 & 0.69 & 0.75 & 0.77 & 0.50 & 7.75 & 0.29 & -0.09 \\
PAL & 10.67 & 6.27 & 1.88 & 0.65 & 0.75 & 0.77 & 0.17 & 8.51 & 0.22 & $0.08^{*}$ \\
PAP & 9.67 & 5.60 & 1.75 & 0.59 & 0.72 & 0.74 & 0.17 & 7.82 & 0.13 & 0.02 \\
PIA & 8.50 & 5.77 & 1.59 & 0.64 & 0.65 & 0.67 & 0.00 & 7.16 & 0.02 & -0.08 \\
PRE & 9.33 & 5.21 & 1.72 & 0.58 & 0.70 & 0.72 & 0.33 & 7.71 & 0.23 & 0.04 \\
SOR & 10.67 & 6.91 & 1.91 & 0.56 & 0.75 & 0.77 & 0.17 & 9.10 & 0.25 & $0.09^{*}$ \\
VER & 9.50 & 5.74 & 1.77 & 0.66 & 0.73 & 0.75 & 0.17 & 7.68 & 0.13 & 0.03 \\
SIC & 8.83 & 4.27 & 1.60 & 0.61 & 0.70 & 0.71 & 0.33 & 6.74 & 0.19 & -0.03 \\
Mean & 9.15 & 5.41 & 1.70 & 0.61 & 0.71 & 0.73 & 0.27 & 7.52 & 0.22 & -0.02 \\
\hline
\end{tabular}

* Significance of inbreeding coefficient Fis was tested using a non-parametric approach described in Exoffier et al., (1992) with 1,000 permutations: $* \mathrm{p}<0.05$ 
Table 5. The hierarchical AMOVA (Excoffier et al., 2005) and F-Statistics analysis calculated considering the main gene pools obtained with PCoA and Structure analysis

\begin{tabular}{lllll}
\hline Source of variation & df & Variance components & \% of variation & F statistics \\
\hline Among groups & 2 & $0.03563 \mathrm{Va}$ & 2.24 & Fct $0.02241^{*}$ \\
$\begin{array}{l}\text { Among population } \\
\text { within groups }\end{array}$ & 14 & $0.02865 \mathrm{Vb}$ & 1.8 & Fsc $0.01844^{*}$ \\
$\begin{array}{l}\text { Among individuals } \\
\text { within populations }\end{array}$ & 305 & $0.01538 \mathrm{Vc}$ & 1 & Fis $0.01038^{*}$ \\
$\begin{array}{l}\text { Within individuals } \\
\text { Nen }\end{array}$ & 322 & $1.50932 \mathrm{Vd}$ & 94.96 & Fit $0.05040^{*}$ \\
\hline
\end{tabular}

$* \mathrm{P}<0.001$ 
Table 6. Unbiased Nei's genetic distance matrix for 17 Q. trojana populations

\begin{tabular}{|c|c|c|c|c|c|c|c|c|c|c|c|c|c|c|c|c|c|}
\hline GIU & LOC & MAC & PARA & SAN & SIC & TM & COL & CRO & GAL & MAN & PAL & PAP & PIA & PRE & SOR & VER & \\
\hline 0.000 & & & & & & & & & & & & & & & & & GIUS \\
\hline 0.193 & 0.000 & & & & & & & & & & & & & & & & LOC \\
\hline 0.420 & 0.416 & 0.000 & & & & & & & & & & & & & & & MAC \\
\hline 0.166 & 0.228 & 0.526 & 0.000 & & & & & & & & & & & & & & PARA \\
\hline 0.240 & 0.167 & 0.498 & 0.183 & 0.000 & & & & & & & & & & & & & SAN \\
\hline 0.295 & 0.195 & 0.211 & 0.323 & 0.298 & 0.000 & & & & & & & & & & & & SIC \\
\hline 0.295 & 0.368 & 0.242 & 0.387 & 0.304 & 0.231 & 0.000 & & & & & & & & & & & $\mathrm{TM}$ \\
\hline 0.251 & 0.266 & 0.236 & 0.295 & 0.258 & 0.157 & 0.093 & 0.000 & & & & & & & & & & $\mathrm{COL}$ \\
\hline 0.203 & 0.208 & 0.276 & 0.272 & 0.222 & 0.140 & 0.134 & 0.081 & 0.000 & & & & & & & & & CRO \\
\hline 0.233 & 0.269 & 0.277 & 0.306 & 0.250 & 0.189 & 0.087 & 0.072 & 0.071 & 0.000 & & & & & & & & GAL \\
\hline 0.246 & 0.267 & 0.263 & 0.245 & 0.324 & 0.210 & 0.218 & 0.158 & 0.122 & 0.140 & 0.000 & & & & & & & MAN \\
\hline 0.260 & 0.275 & 0.194 & 0.305 & 0.258 & 0.169 & 0.114 & 0.100 & 0.107 & 0.107 & 0.133 & 0000 & & & & & & PAL \\
\hline 0.263 & 0.303 & 0.231 & 0.327 & 0.265 & 0.184 & 0.095 & 0.089 & 0.090 & 0.065 & 0.138 & 0.076 & 0.000 & & & & & PAP \\
\hline 0.289 & 0.262 & 0.201 & 0.384 & 0.285 & 0.146 & 0.115 & 0.077 & 0.064 & 0.094 & 0.164 & 0.120 & 0.094 & 0.000 & & & & PIA \\
\hline 0.317 & 0.341 & 0.235 & 0.395 & 0.317 & 0.203 & 0.098 & 0.113 & 0.096 & 0.105 & 0.127 & 0.084 & 0.074 & 0.122 & 0.000 & & & PRE \\
\hline 0.230 & 0.226 & 0.211 & 0.289 & 0.237 & 0.147 & 0.138 & 0.085 & 0.058 & 0.075 & 0.108 & 0.090 & 0.083 & 0.066 & 0.095 & 0.000 & & SOR \\
\hline 0.242 & 0.274 & 0.212 & 0.303 & 0.256 & 0.166 & 0.099 & 0.068 & 0.079 & 0.064 & 0.151 & 0.080 & 0.063 & 0.086 & 0.087 & 0.059 & 0.000 & VER \\
\hline
\end{tabular}




\section{Figure Captions}

Fig. 1. Map illustrating the location of the 17 Italian populations of $Q$. trojana Webb analysed in this study.

Fig. 2. Principal coordinate analysis of 17 Q. trojana populations from southern Italy (Apulia and Sicily).

Fig. 3. Population structure inferred for 17 Q. trojana populations using the STRUCTURE software (Pritchard et al. 2000): (A) Second order of change of the log-likelihood of data $(\Delta K)$ as function of $\mathrm{K}$, calculated over six replicates. (B) Individual's estimated membership percentage in K clusters (Q values), each individual is represented by vertical line, the different populations are separated by a vertical black line. (C) Map representation of the population's membership percentage (Qi) in the inferred $\mathrm{K}=4$ clusters.

Fig. 4. Principal coordinate analysis of $Q$. trojana Italian populations and eastern Mediterranean samples (Greece and Turkey). GR= Greece, NW= North-Western Turkey, CW= Central-Western Turkey, SW=South-Western Turkey. Circle includes populations from Martina Franca area and Greek samples. 


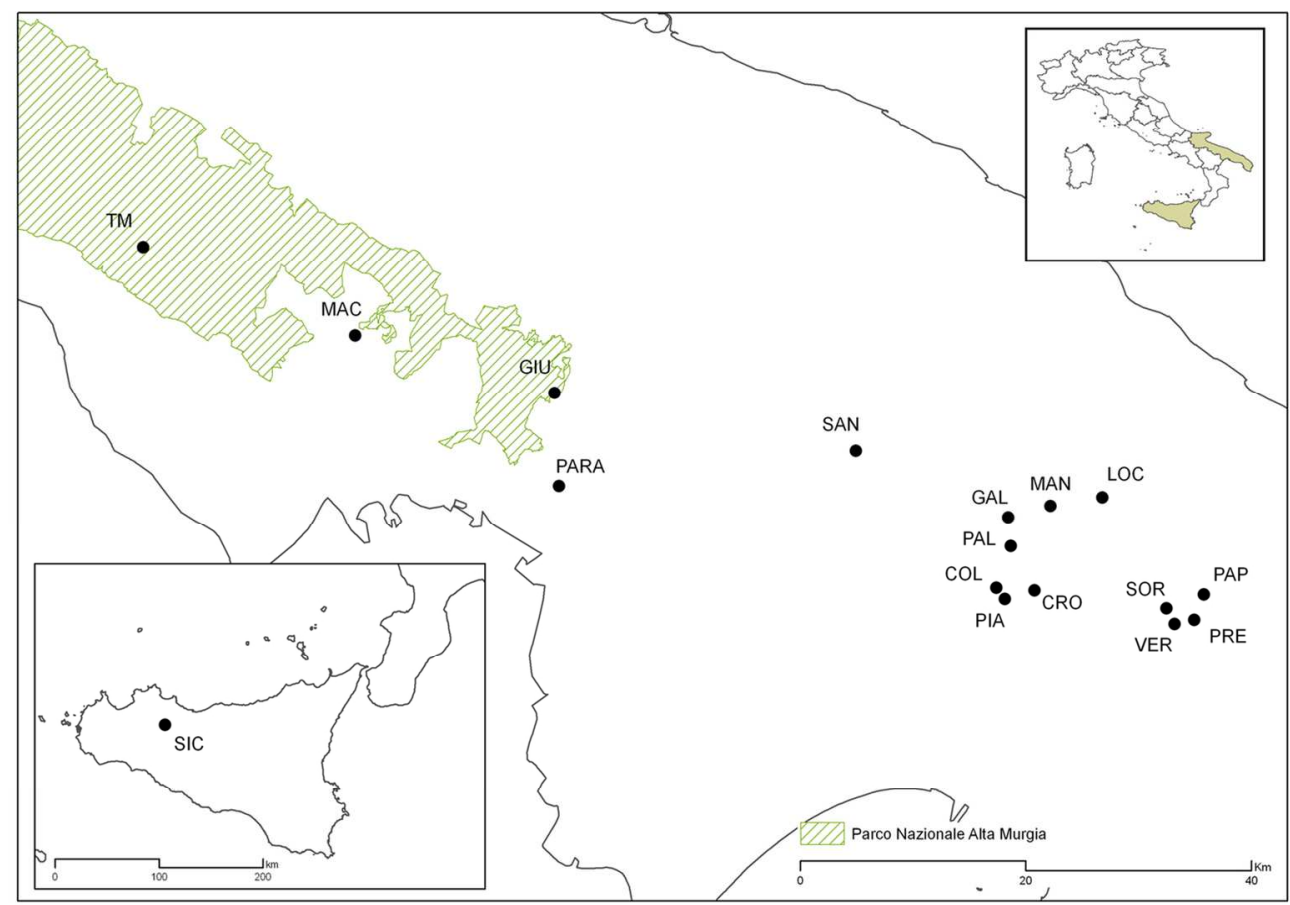

Fig. 1. Map illustrating the location of the 17 Italian populations of $Q$. trojana Webb analysed in this study. $128 \times 91 \mathrm{~mm}(300 \times 300 \mathrm{DPI})$ 


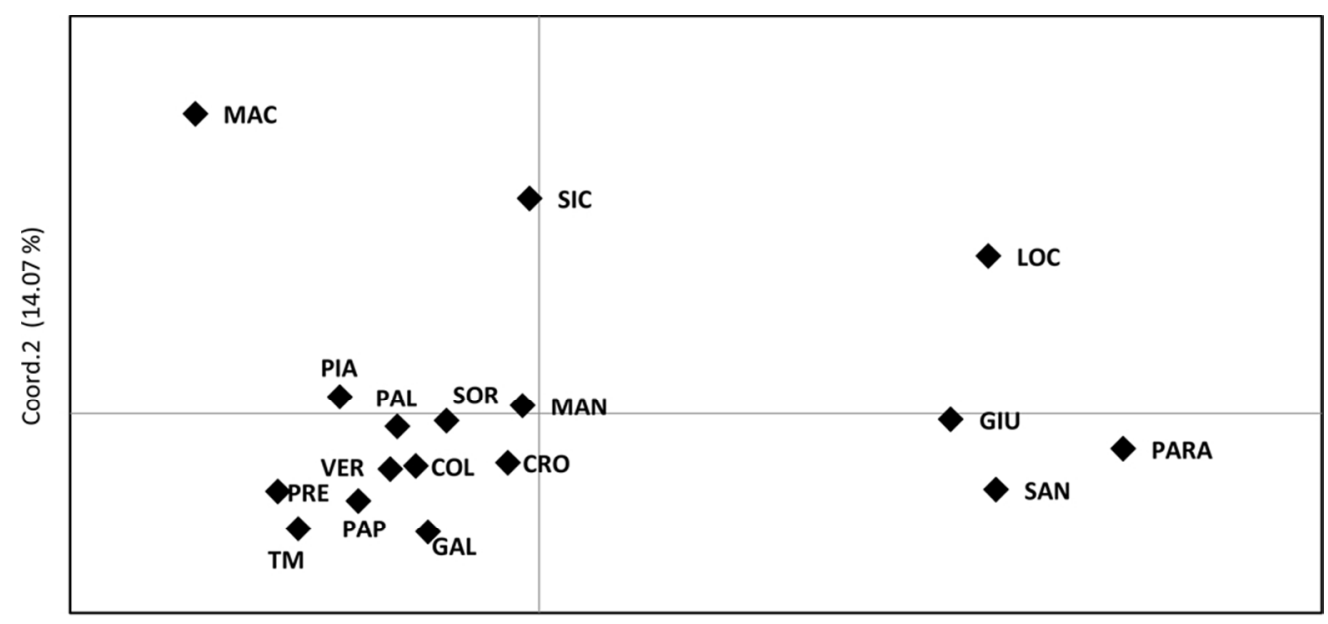

Coord.1 (34.24\%)

Fig. 2. Principal coordinate analysis of 17 Q. trojana populations from southern Italy (Apulia and Sicily). $91 \times 44 \mathrm{~mm}(300 \times 300 \mathrm{DPI})$ 

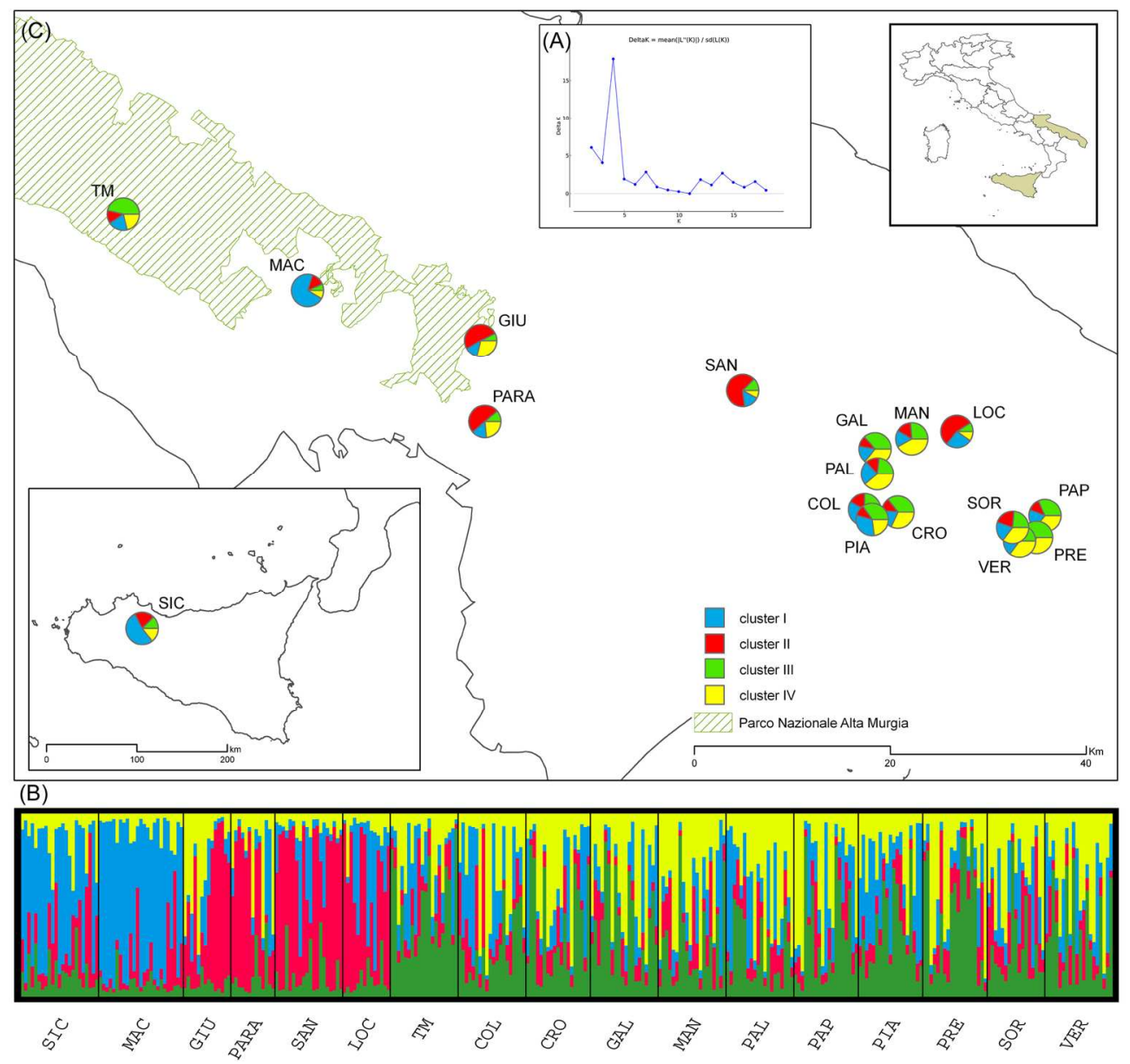

Fig. 3. Population structure inferred for $17 \mathrm{Q}$. trojana populations using the STRUCTURE software (Pritchard et al. 2000): (A) Second order of change of the log-likelihood of data $(\Delta K)$ as function of $K$, calculated over six replicates. (B) Individual's estimated membership percentage in $\mathrm{K}$ clusters ( $\mathrm{Q}$ values), each individual is represented by vertical line, the different populations are separated by a vertical black line. (C) Map representation of the population's membership percentage $(\mathrm{Q} i)$ in the inferred $\mathrm{K}=4$ clusters.

$170 \times 159 \mathrm{~mm}(300 \times 300 \mathrm{DPI})$ 


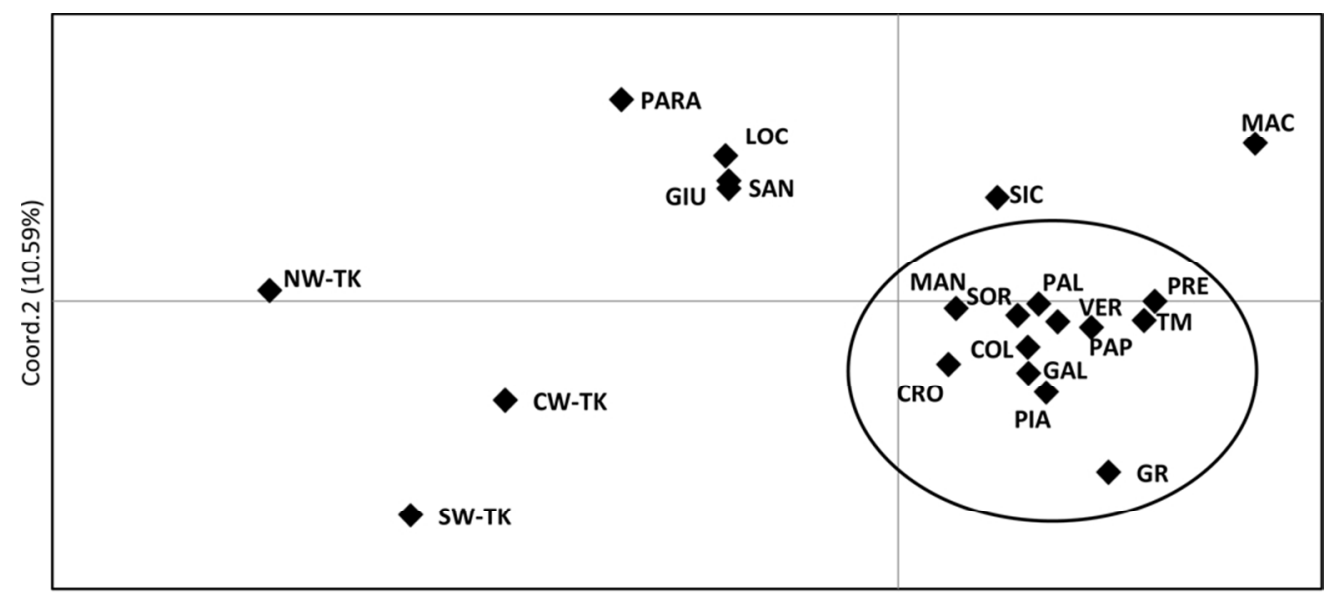

Coord.1 (53.25\%)

Fig. 4. Principal coordinate analysis of $Q$. trojana Italian populations and eastern Mediterranean European samples (Greece and Turkey). GR= Greece, NW= North-Western Turkey, CW= Central-Western Turkey, $\mathrm{SW}=$ South-Western Turkey. Circle includes populations from Martina Franca area and Greek samples.

$91 \times 43 \mathrm{~mm}(300 \times 300 \mathrm{DPI})$ 


\begin{tabular}{lll}
\hline $\mathbf{K}$ & \multicolumn{1}{c}{ Fct } & \multicolumn{1}{c}{ Fsc } \\
\hline $\mathbf{2}$ & $\mathbf{0 . 0 5 5 4 3}$ & $\mathbf{0 . 0 2 1 9 7 * *}$ \\
$\mathbf{3}$ & 0.04134 & $0.02087^{* *}$ \\
$\mathbf{4}$ & $0.03544^{* *}$ & $0.01847^{* *}$ \\
$\mathbf{5}$ & $0.03325^{* *}$ & $0.01592^{* *}$ \\
$\mathbf{6}$ & $0.03345^{* *}$ & $0.00902^{* *}$ \\
$\mathbf{7}$ & $0.03353^{* *}$ & $0.00658^{* *}$ \\
$\mathbf{8}$ & $0.03385^{* *}$ & $0.00608^{* *}$ \\
$\mathbf{9}$ & $0.03428^{* *}$ & $0.00052^{* *}$ \\
$\mathbf{1 0}$ & $0.03465^{* *}$ & $-0.00089^{* *}$ \\
$\mathbf{1 1}$ & $0.03521^{* *}$ & $-0.00226^{* *}$ \\
$\mathbf{1 2}$ & $0.03620^{* *}$ & $-0.00402^{* *}$ \\
$\mathbf{1 3}$ & $0.03655^{* *}$ & $-0.00492^{* *}$ \\
$\mathbf{1 4}$ & $0.03726^{* *}$ & -0.00578 \\
$\mathbf{1 5}$ & $0.03799^{* *}$ & $-0.00682^{*}$ \\
$\mathbf{1 6}$ & $0.03958^{*}$ & $-0.00903^{* *}$ \\
\hline$* * \mathrm{P}<0.001$ & \\
$* \mathrm{P}<0.05$ &
\end{tabular}

